\title{
Intervju ved judisiell observasjon
}

\author{
Er kravet om fortrinnsvis å intervjue en rettspsykiatrisk observand \\ alene - og ikke sammen med annen sakkyndig - begrunnet i lover eller \\ forskrifter? Eller er spørsmålet heller et faglig medisinsk/psykiatrisk \\ spørsmål?
}

Kan et intervju med en observand som er under judisiell observasjon gjøres med to psykiatrisk sakkyndige til stede, eller må slike intervjuer foretas med bare en av de sakkyndige nærværende? Er psykiatrisk sakkyndige som har et faglig avhengighetsforhold til hverandre, inhabile ved å ha vært sjef/underordnet og/eller har foretatt mange tidligere rettspsykiatriske erklæringer sammen? Dette var temaer som ble mye diskutert $\mathrm{i}$ forbindelse med rettssaken etter terroren 22. juli 2011.

\section{Hva sier jusen?}

Vi har ikke funnet noe juridisk eller forskriftsmessig eller særlige offentlige skriv som skulle regulere dette spørsmålet. Det forekommer for øvrig heller ikke i det standardiserte mandatet som norske domstoler bruker ved oppnevnelse av rettspsykiatrisk sakkyndige.

\section{Hva sier rettspsykiatriske lærebøker?}

Aktuelle lærebøker i norsk rettspsykiatri angir anbefalinger om hva som er forsvarlig medisinsk undersøkelse og diagnostikk ved rettspsykiatrisk virksomhet $(1,2)$. I den ene læreboken sies det om den praktiske arbeidsformen kun at de sakkyndige snakker med observanden sammen eller alene (1). I den andre læreboken henvises det til at straffeprosessloven $\$ 139$ krever en sakkyndig oppnevnt, med mindre retten finner at saken krever to eller flere sakkyndige (2). Og det sies at det å ha to sakkyndige er et «kvalitetssikringstiltak» - uten at dette utdypes. Videre er begrunnelsen for å oppnevne to sakkyndige at de kan «danne seg et bilde av observanden hver for seg» (2). Det nevnes også at det kan være nyttig med et felles besøk i tilfelle divergens i oppfatningen.

Og straffeloven henviser til at «det (...) bør heller ikke oppnevnes sakkyndige som står i avhengighetsforhold til hverandre». Vi vil anta at «inhabilitet» i denne sammenheng også må oppfattes som en mulig innblanding i den enkelte sakkyndiges selvstendige faglige observasjon og vurdering.

\section{Diskusjon}

Hva det innebærer at to sakkyndige skal foreta selvstendige vurderinger, er ikke umiddelbart entydig. Det kan synes rimelig å skjelne mellom selve intervjusituasjonen og den videre intellektuelle bearbeiding, refleksjon og vurdering av informasjon og inntrykk. En psykiatrisk undersøkelsessituasjon vil ha et visst preg av «iscenesettelse»: på tomannshånd med observanden kan den være preget av den aktuelle sakkyndiges holdninger og tilnærming til problemet, i ekstreme tilfeller også av vedkommendes særegenheter. Er man to kolleger, vil det være større mulighet for korrektiver og supplerende kommentarer underveis. På den annen side kan det tenkes at to kolleger som har samarbeidet mye klinisk, i varierende grad påvirker hverandres persepsjon og refleksjon ved fellessamtale med en tredjeperson.

At man skal gjøre sitt arbeid hver for seg, skulle imidlertid ikke trenge bety at man dermed ikke skulle ha en eller flere samtaler med observanden i fellesskap. Det kan også tenkes at en observand vil ha lettere for å tolke relasjonen som en terapeutisk relasjon når bare én sakkyndig er til stede, enn om han sitter overfor to sakkyndige, selv om situasjonen i så måte alltid vil være definert og forklart for en rettspsykiatrisk observand.

Det er vanskelig å se at det å samtale utelukkende med en observand alene, vil være det eneste som bidrar optimalt til å få det best mulig nyanserte og omfattende bilde av personen. Litt karikert kan man spørre seg om man nærmest har sett en slags juridisk parallell til at vitner $\mathrm{i}$ en rettssak skulle kunne påvirke hverandre. Man må kunne spørre om fellessamtaler per definisjon skulle svekke den enkeltes evne og mulighet til å danne seg et «selvstendig bilde av observanden». I og med at hovedformålet med en rettspsykiatrisk observasjon er å få det best mulig nyanserte og omfattende bilde av personen, er det all grunn til å peke på at en samtale med observanden og to sakkyndige til stede samtidig kan frembringe informasjoner som ikke kommer selvfølgelig frem ved en samtale mellom to personer. Det kan
Jon Geir Høyersten

jon.geir.hoyersten@helse-bergen.no Siri Nome

Kompetansesenter for sikkerhets-, fengselsog rettspsykiatri

Helse Bergen 
tenkes å være nyanser i direkte opplysninger eller holdninger som kan gå den ene kollega hus forbi. Dette får betydning både for den delen som omfatter deskriptiv psykopatologi og for det som omhandler personlighetspsykologi og personlighetsforstyrrelser.

En slik felles observasjon har likheter med behandlings- og kartleggingsmetoder i parterapi og familieterapi: to psykiatere kan alternere mellom å være «distansert» observerende og delta aktivt, og vil derved også kunne fange opp forskjellige nyanser i kommunikasjon og atferd. Et observerende «par» vil ved den dynamikk som da skapes, kunne frembringe informasjon ut over summen av de to enkeltobservasjoner. Dette er også en hyppig ramme ved innkomstsamtaler i psykiatriske sykehusavdelinger, både ved tvangsinnleggelser og ved andre innleggelser.

Riktignok har vi den offisielle bokstavelige betegnelsen judisiell observasjon, men på generelt grunnlag vil vi minne om at den psykiatriske undersøkelsen og intervjuet i det store og hele har preg av deltakende observasjon. Dette betyr i korttekst at den kliniske observatør på samme tid er deltaker i en relasjon og ikke kan unngå å bli påvirket av denne -på samme måte som objektet for undersøkelsen påvirkes. Det psykiatriske intervju er et vel fundert klinisk instrument, og hjørnesteinen ved all psykiatrisk utredning (3).

Formålet med judisiell observasjon er definert ut fra straffeloven og gir en viss avgrensning om hva man skal frem til. Men innholdet og fremgangsmåten ved observasjonen vil måtte representeres av hva som i dag er anerkjent teoretisk og praktisk psykiatrisk forståelse og virksomhet.

\section{Inhabilitet?}

Hva så med spørsmålet om inhabilitet når f.eks. to sakkyndige skulle ha et faglig avhengighetsforhold ved et overordnet/underordnet arbeidsforhold og/eller ved tidligere å ha foretatt felles rettspsykiatriske undersøkelser. Inhabilitet vil i første rekke være definert ut fra forvaltningsloven. Hva slags særlige fordeler det her kunne være tale om kan - i norsk sammenheng - neppe dreie seg om økonomi. Fordeler i ansettelsesforhold kan teoretisk tenkes å være et poeng; liksom et fortsatt godt og knirkefritt kollegialt samarbeid ikke burde preges av altfor stor faglige uoverensstemmelser. Men at slike forhold på avgjørende vis skulle påvirke observasjoner og konklusjoner i mindre objektiv lei, har vi vanskelig for å se.

\section{Konklusjon}

Vår konklusjon er at den praktiske gjennomføringen av intervjudelen av en judisiell observasjon ikke er juridisk, men medisinsk forankret. Vi mener at et antydet ideal om uavhengig vurdering er godt ivaretatt og sikret vel så godt ved at to sakkyndige gjennomfører sine samtaler med en observand $\mathrm{i}$ fellesskap.

\section{Jon Geir Høyersten (f. 1942)}

er spesialist i psykiatri og dr.philos. Han har virket som rettspsykiatrisk sakkyndig i mange år og er forsker.

Forfatter har fylt ut ICMJE-skjemaet og oppgir ingen interessekonflikter.

\section{Siri Nome (f. 1944)}

er spesialist i psykiatri. Hun har virket som rettspsykiatrisk sakkyndig i mange år og er direktør.

Forfatter har fylt ut ICMJE-skjemaet og oppgir ingen interessekonflikter.

\section{Litteratur}

1. Dalgard OS, Høyer G. Lærebok i rettspsykiatri. Oslo: Gyldendal, 2002: 233-6.

2. Rosenqvist R, Rasmussen K. Rettspsykiatri i praksis. Oslo: Universitetsforlaget, 2001: 78-81.

3. Manley MR. Psychiatric interview. History and mental status examination. I: Kaplan \& Sadock's Comprehensive textbook of psychiatry. Utg.VII. Philadelphia, PA: Lippincott Williams \& Wilkins, 2000: 652-64.

Mottatt 7.11. 2012, første revisjon innsendt 27.11. 2012. godkjent 27.11. 2012. Medisinsk redaktør Petter Gjersvik.

Podkast på www.tidsskriftet.no 